\title{
OPTIMISATION OF THE MECHANICAL PROPERTIES \\ OF A NEW PM SUPERALLOY FOR DISK APPLICATIONS
}

\author{
D. Locq, M. Marty and P. Caron \\ Office National d'Etudes et de Recherches Aérospatiales (ONERA) \\ BP 72 - 92322 Châtillon Cedex - France
}

\begin{abstract}
The roles of the subsolvus solutioning temperalure and of the ageing temperature on the microstructure and on tensile and creep properties were evaluated on a new PM superalloy, designated NR3. A single-stage ageing treatment was applied instead of the usual double-stage ageing treatment. The principal objective was to improve the creep resistance of this superalloy while keeping a high tensile strength by using a simplified heat treatment.
\end{abstract}

The solution treatment essentially affected the respective proportions of primary and secondary $\gamma^{\prime}$ precipitates and the grain size. On the other hand, the major influence of the increase of the ageing temperature was to coarsen the tertiary $\gamma^{\prime}$ particles. These microstructural effects were successfully combined to obtained a significant increase of the creep strength associated with a slight rise of the tensile properties.

\section{Introduction}

Nickel base superalloy disks processed by the powder metallurgy (PM) route exhibit a high level of mechanical properties due to their homogeneous fine-grained microstructure and due to high levels of alloying elements which can be added. A number of alloys for disk applications were thus developed with the aim to get optimum properties, mainly by optimisation of their chemistry.

Another way to improve the mechanical properties of these materials is to control their microstructure by varying thermal and/or thermomechanical parameters. The main microstructural characteristics are the grain size, the volume fraction and the distribution of the strengthening $\gamma^{\prime}$ phase precipitates and the intergranular carbide/boride precipitation. In a number of studies, these parameters were modified essentially by choosing between subsolvus or supersolvus solution treatments leading respectively to fine-grained or coarse-grained microstructures, and/or by varying the cooling rate after this high temperature treatment, thus controlling the size of the secondary $\gamma^{\prime}$ precipitates. On the other hand, the effects of the ageing treatments usually applied after the solution treatment were only scarcely studied.

The alloy selected for this work was NR3 (1), recently developed at ONERA in order to satisfy the requirements for high temperature disk applications. This alloy was selected amongst a series of experimental alloys derived from the reference N18 alloy $(2,3)$. The experimental chemistries were defined in order to avoid the precipitation of intergranular and intragranular topologically close-packed (TCP) phase particles that occurs in the N18 alloy during exposures at temperatures above $650^{\circ} \mathrm{C} \mathrm{(4),}$ while showing comparable or higher mechanical properties (5). The NR3 alloy had a coarse-grained microstructure obtained through a supersolvus solution treatment which improves the creep strength at high temperatures. In these conditions the NR3 alloy therefore exhibited a satisfactory balance between tensile and creep properties, while showing no propensity for TCP phase precipitation at temperatures above $650^{\circ} \mathrm{C}$.

The purpose of the present work was to identify an optimised $\gamma^{\prime}$ particle distribution obtained through an appropriate ageing treatment procedure in order to further improve the creep strength, while keeping a fine-grained microstructure with the aim to maintain a high level of tensile properties.

\section{Alloy Development}

The NR3 alloy was the result of the study of a series. of nine experimental superalloys designed, processed and evaluated at 
ONERA (5). Its common features with the N18 alloy were :

a $\gamma^{\prime}$ atomic fraction maintained at $0.50-0.55$

a Co content of 15 wt. \%

a $\mathrm{Cr}$ content fixed at 25 at. \% in the $\gamma$ matrix to maintain a good environmental resistance at high temperatures especially during crack propagation

minor elements contents (C, B, $\mathrm{Zr}$ and $\mathrm{Hf}$ ) close to those of N18 alloy.

The Mo content was lowered in order to decrease the $\overline{\mathrm{Md}}$ parameter and in this way to avoid the precipitation of TCP phases. The stability criterion $\overline{\mathrm{Md}}$ was calculated using the New Phacomp method (6) and a critical value for TCP phase precipitation was determined to be 0.915 by previous experiments. To counterbalance the loss of solid solution strengthening, the Ti/Al ratio was increased to 0.9 (vs 0.6 for N18 alloy (at. \%)). The chemistry of the NR3 alloy was balanced by using a program based on the method developed by Watanabe for calculation of the fraction of $\gamma^{\prime}$ phase and the composition of the $\gamma$ and the $\gamma^{\prime}$ phases from the alloy chemistry (7). The density of this alloy was estimated using the formula developed by Hull (8). After supersolvus solution treatment, the NR3 alloy exhibited tensile and creep properties very close to or better than those of N18 alloy. At last, even after a long-time exposure of 10000 hours at $750^{\circ} \mathrm{C}$, no intragranular TCP phases were observed in NR3 alloy.

\section{Experimental Procedures}

An as-forged pancake of NR3 alloy was processed by Tecphy and SNECMA using the N18 industrial route : i) vacuum induction melting, ii) argon atomisation, iii) screening $(\phi<75 \mu \mathrm{m}(-200$ mesh)), iv) hot extrusion and v) isothermal forging. The chemical composition is reported in Table I. The density of NR3 alloy was measured to be $8.05 \mathrm{~g} . \mathrm{cm}^{-3}$.

Table I NR3 Alloy Composition (wt. \%)

\begin{tabular}{rccccccccc}
\hline $\mathrm{Ni}$ & $\mathrm{Co}$ & $\mathrm{Cr}$ & $\mathrm{Mo}$ & $\mathrm{Al}$ & $\mathrm{Ti}$ & $\mathrm{Hf}$ & $\mathrm{B}$ & $\mathrm{C}$ & $\mathrm{Zr}$ \\
\hline bal. & 14.65 & 11.8 & 3.3 & 3.65 & 5.5 & 0.33 & 0.013 & 0.024 & 0.052 \\
\hline
\end{tabular}

Solution heat treatments were conducted in argon below the $\gamma^{\prime}$ solvus temperature. The subsequent cooling was performed at a controlled rate of about $100 \mathrm{~K} \cdot \mathrm{min}^{-1}$ that is representative of the industrial conditions.

Primary $\gamma^{\prime}$ area fraction and grain size were determined by image analysis of pictures acquired by optical microscopy. Microstructural observations of $\gamma^{\prime}$ precipitates and dislocation structures were performed by transmission electron microscopy (TEM) using a JEOL $200 \mathrm{CX}$ microscope operating at $200 \mathrm{kV}$. Thin foils were prepared by electrochemical polishing in a twinjet polisher using a solution of $45 \%$ acetic acid, $45 \%$ butylcellosolve and $10 \%$ perchloric acid, cooled to $263 \mathrm{~K}$ and using a potential of $25 \mathrm{~V}$.

Vickers microhardness tests were performed in air at room temperature under a load of $1 \mathrm{~kg}$. The results presented are the average of 5 to 10 measurements. Tensile tests were conducted in air at 400 and $700^{\circ} \mathrm{C}$ on $4 \mathrm{~mm}$ diameter cylindrical specimens with an initial strain rate of $1.7 \times 10^{-3} \mathrm{~s}^{-1}$. Tensile creep tests were conducted in air at $700^{\circ} \mathrm{C}$ on $3 \mathrm{~mm}$ diameter cylindrical specimens.

\section{Experimental Results}

\section{Heat Treatment and Microstructure Selection}

Introduction. A standard heat treatment ("SHT") based on that applied to N18 alloy has been defined for NR3 alloy. This treatment consists of a subsolvus solution treatment $(30 \mathrm{~K}$ below the $\gamma^{\prime}$ solvus temperature) followed by two ageing treatments. The $\gamma^{\prime}$ solvus temperature was measured to be close to $1205^{\circ} \mathrm{C}$ (by isothermal treatments and optical metallography). So, the NR3 SHT is :

$$
1175^{\circ} \mathrm{C} / 4 \mathrm{~h}+700^{\circ} \mathrm{C} / 24 \mathrm{~h}+800^{\circ} \mathrm{C} / 4 \mathrm{~h} \text {. }
$$

The necessity for two ageing treatments is not clearly justified and understood and some authors even asked themselves about the influence of each ageing treatment $(4,9)$. On this basis and with the goal of a better understanding of the ageing effect on the microstructure, single-stage ageing treatments were tested after the solution heat treatment.

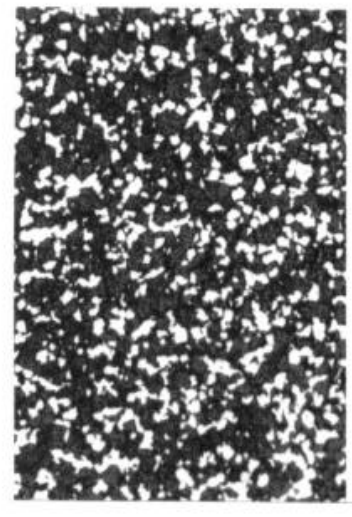

(a)

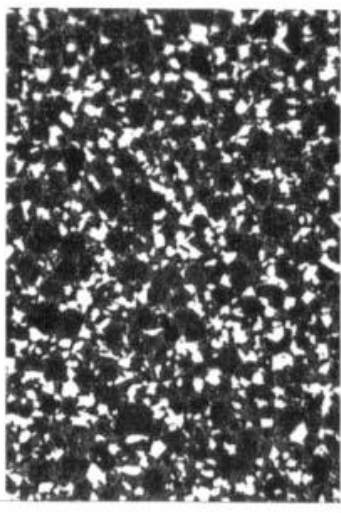

(b)

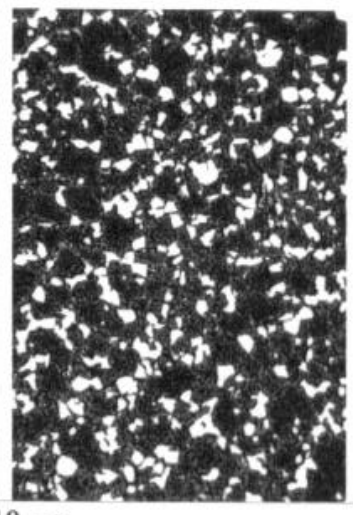

(c)

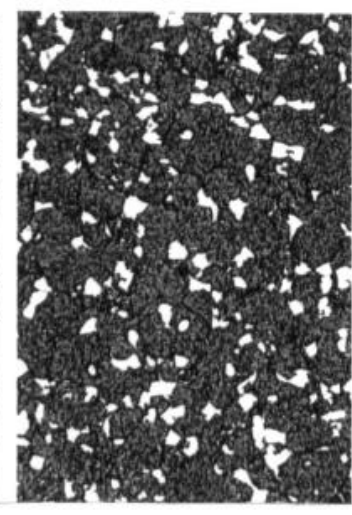

(d)

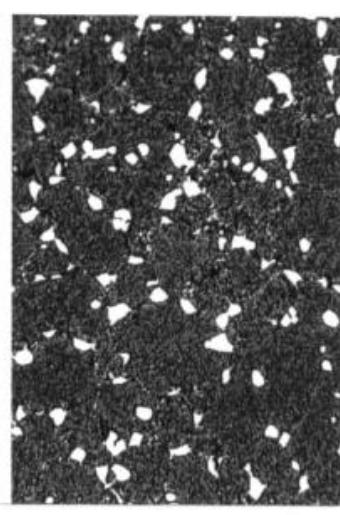

(e)

Figure 1: Variation of the area fraction of the primary $\gamma^{\prime}$ with the solutioning temperature (optical micrographs) : (a) $1145^{\circ} \mathrm{C} / 4 \mathrm{~h},(\mathrm{~b})$ $1165^{\circ} \mathrm{C} / 4 \mathrm{~h}$, (c) $1175^{\circ} \mathrm{C} / 4 \mathrm{~h}$, (d) $1185^{\circ} \mathrm{C} / 4 \mathrm{~h}$ and (e) $1195^{\circ} \mathrm{C} / 4 \mathrm{~h}$. 
Effect of the Subsolvus Solution Treatment. Six solutioning temperatures were chosen between the forging temperature and the $\gamma^{\prime}$ solvus temperature (i.e. between 1120 and $1205^{\circ} \mathrm{C}$ ). The duration of these treatments was 4 hours.

The micrographs of Figure 1 show the variation in the primary $\gamma^{\prime}$ fraction with the solutioning temperature. The area fraction of primary $\gamma^{\prime}$ and the average grain size $v s$ the solutioning temperature are plotted in Figure 2. It can be seen that even $4 \mathrm{~K}$ below the $\gamma^{\prime}$ solvus temperature, $5 \%$ of primary $\gamma^{\prime}$ remained. This gradual dissolution of the primary $\gamma^{\prime}$ led to a relatively slow growth of the grain size especially in the range $1145-1185^{\circ} \mathrm{C}$. Above $1185^{\circ} \mathrm{C}$, the average grain size increased more quickly because there were no more enough primary $\gamma^{\prime}$ precipitates to pin the grain boundaries which begin to move.

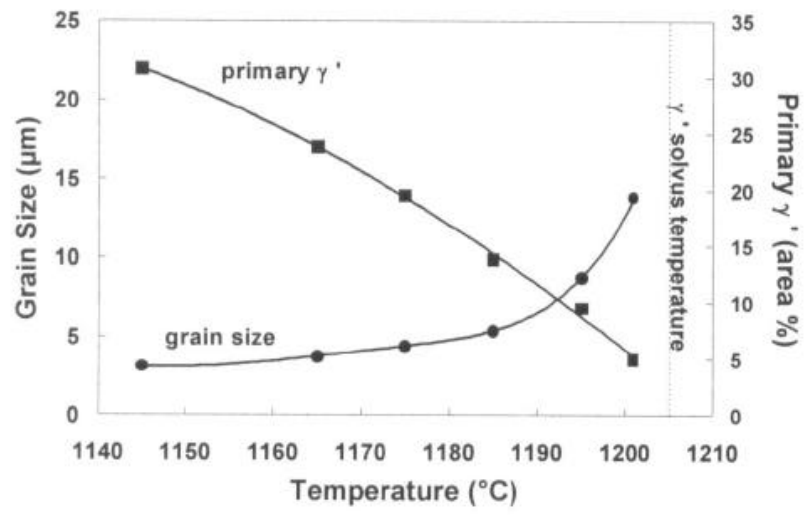

Figure 2: Variation of the grain size and the area fraction of primary $\gamma^{\prime}$ with the solutioning temperature.

Another microstructural parameter affected by the solutioning temperature is the average size of the secondary $\gamma^{\prime}$ precipitates. Actually, the average dimension of the edge of these precipitates was about $130 \mathrm{~nm}$ after 4 hours at $1145^{\circ} \mathrm{C}$ and moved to about $190 \mathrm{~nm}$ after 4 hours at $1195^{\circ} \mathrm{C}$ (see Figure 3). The distribution and the size of the tertiary $\gamma^{\prime}$ precipitates were not significantly affected by this heat treatment.

Microhardness tests were performed at room temperature on some specimens. This is a simple test commonly used for mechanical characterisation of microstructure evolution $(4,9)$. The average values are presented in Table II.

Table II Effect of Solutioning Temperature on Microhardness

\begin{tabular}{cc}
\hline $\begin{array}{c}\text { Solutioning } \\
\text { temperature }\end{array}$ & $\begin{array}{c}\text { Microhardness } \\
\text { HV 1 kg }\end{array}$ \\
\hline As-forged & 430 \\
$1145^{\circ} \mathrm{C} / 4 \mathrm{~h}$ & 422 \\
$1175^{\circ} \mathrm{C} / 4 \mathrm{~h}$ & 411 \\
$1195^{\circ} \mathrm{C} / 4 \mathrm{~h}$ & 407 \\
\hline
\end{tabular}

A slight decrease of the microhardness was observed with the increase of the solutioning temperature. The increase of the fraction of secondary and tertiary $\gamma^{\prime}$ precipitates which contribute to the strengthening of the alloy was very likely balanced by the increase of the grain size and the secondary $\gamma^{\prime}$ precipitate size.

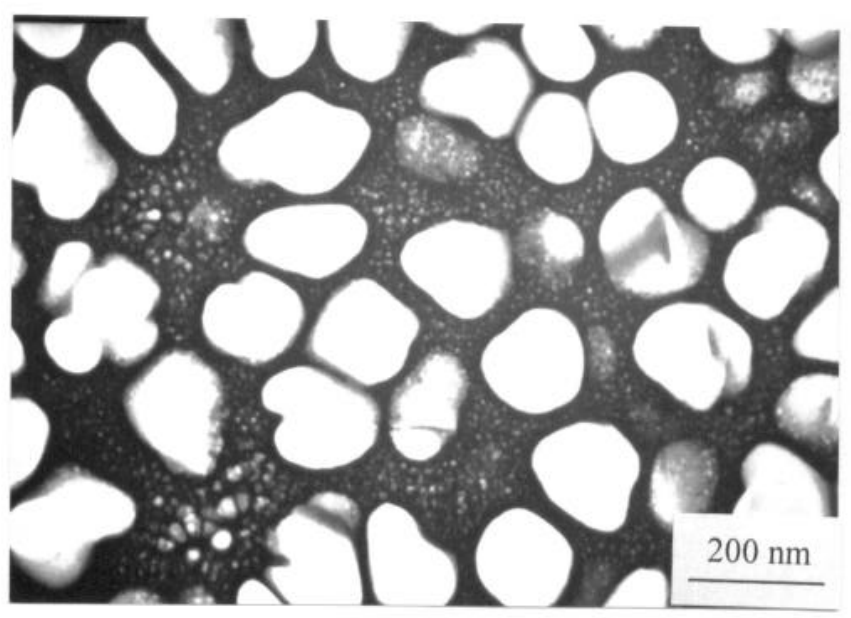

(a)

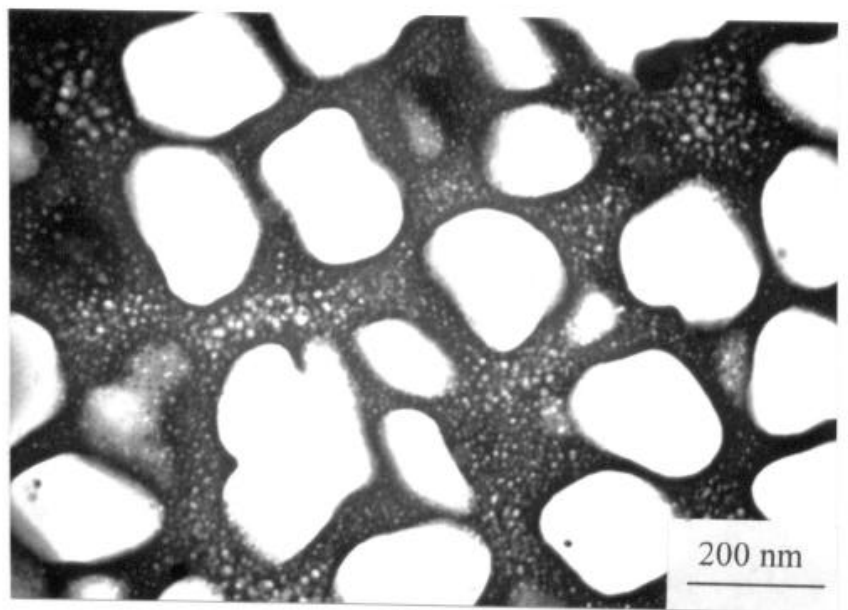

(b)

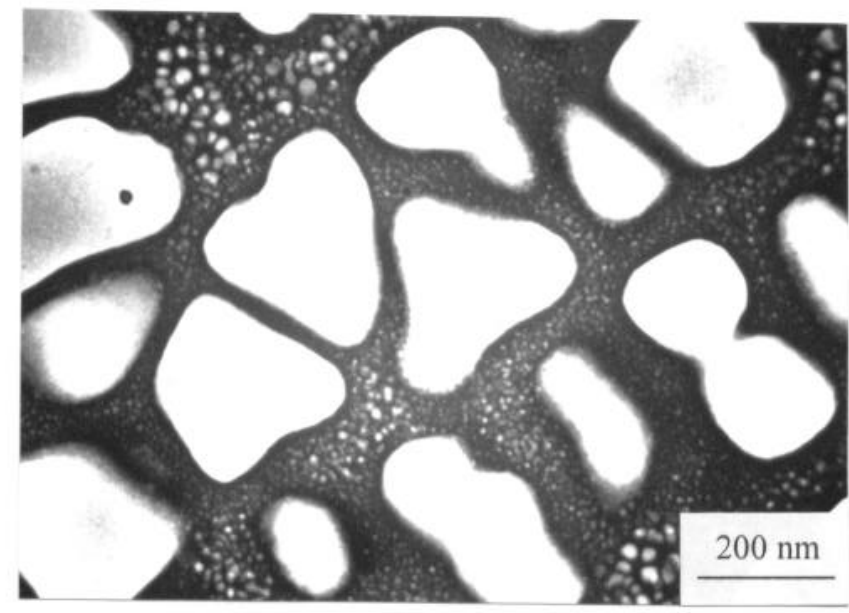

(c)

Figure 3: Effect of the solutioning temperature on the $\gamma^{\prime}$ precipitation ( + ageing treatment : $750^{\circ} \mathrm{C} / 4 \mathrm{~h}$ ), (TEM dark field micrographs using $\gamma^{\prime}$ diffraction spots) : (a) $1145^{\circ} \mathrm{C} / 4 \mathrm{~h}$, (b) $1175^{\circ} \mathrm{C} / 4 \mathrm{~h}$ and (c) $1195^{\circ} \mathrm{C} / 4 \mathrm{~h}$. 


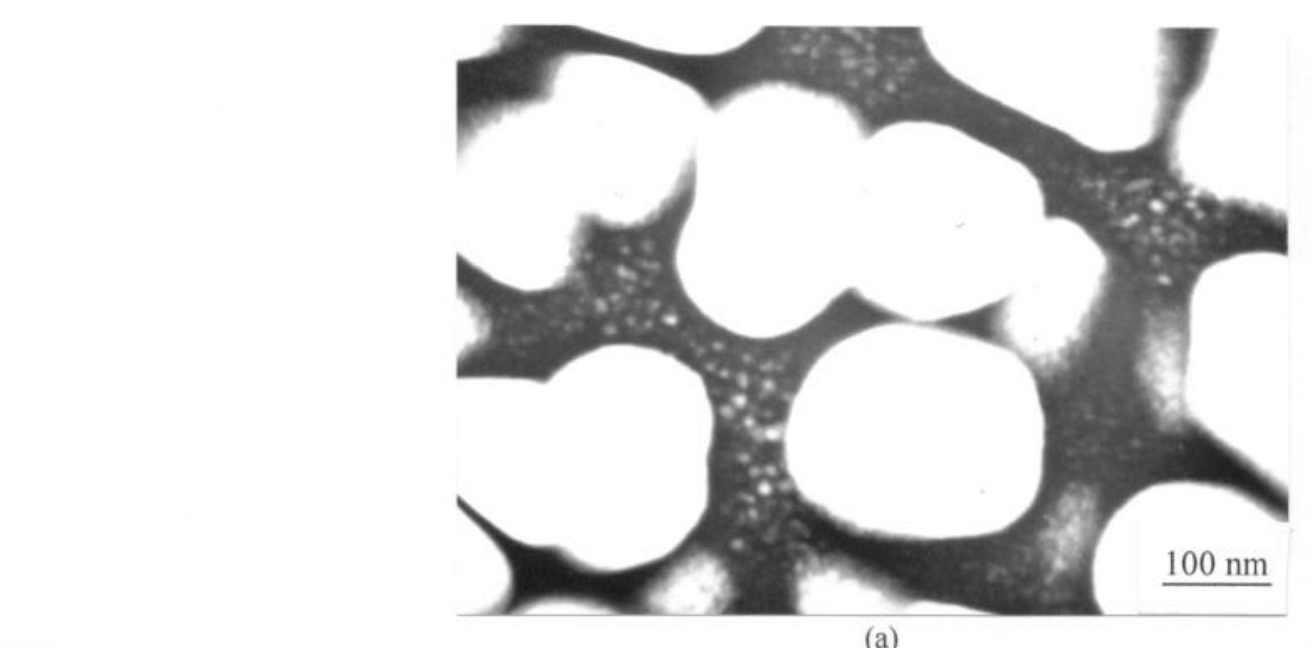

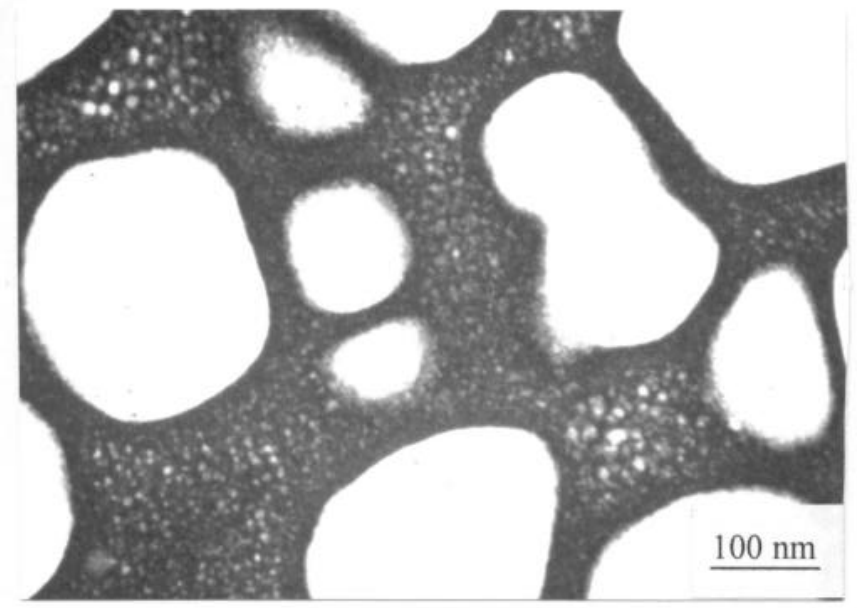

(b)

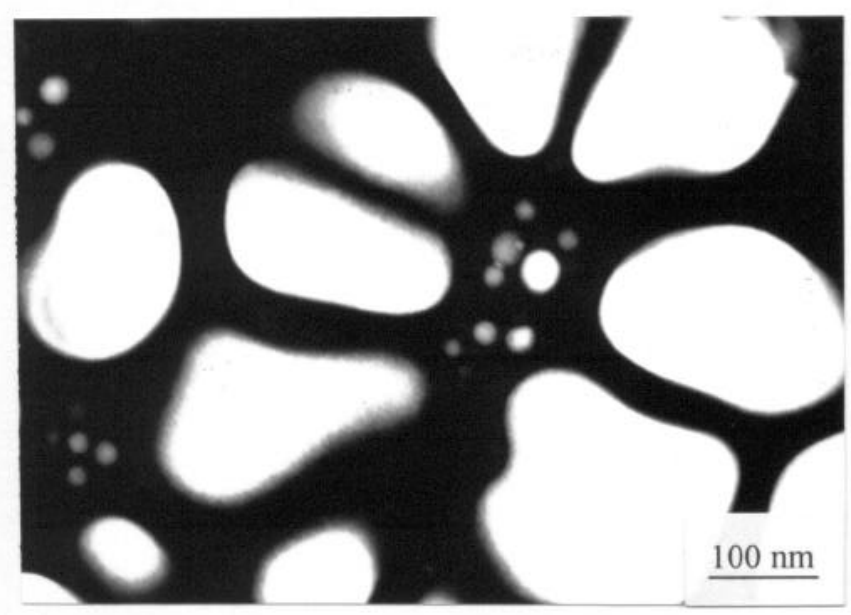

(d)

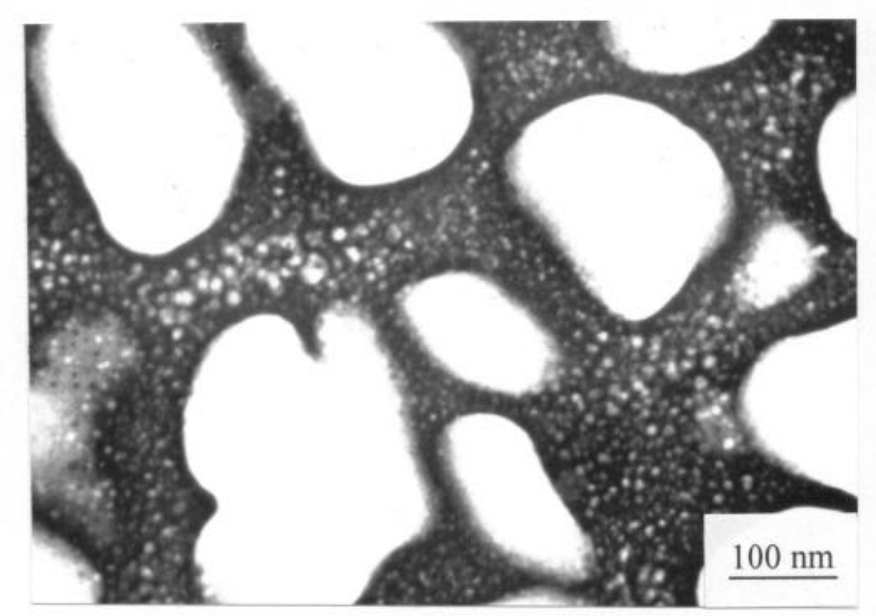

(c)

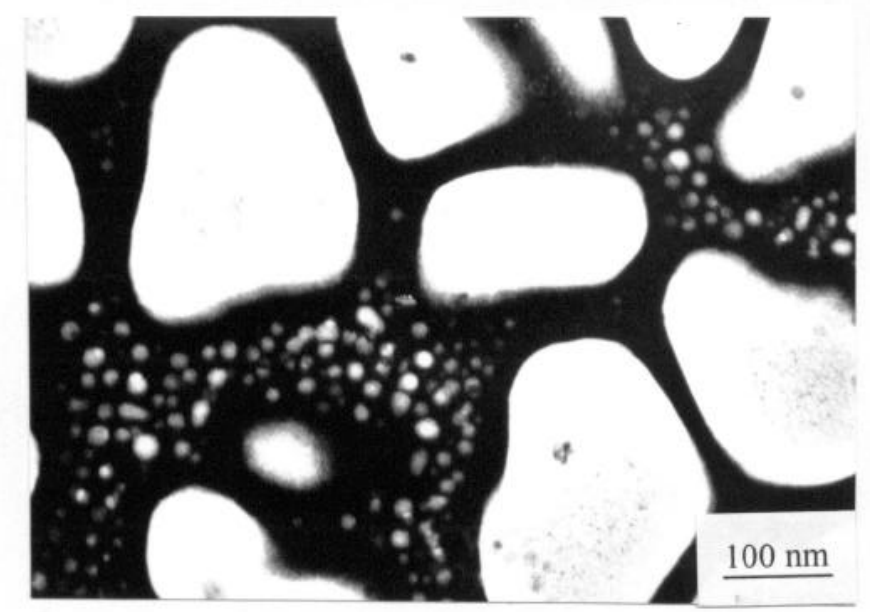

(e)

Figure 4: Effect of the ageing sequence on the $\gamma$ 'precipitation (solution treatment $1175^{\circ} \mathrm{C} / 4 \mathrm{~h}\left(100 \mathrm{~K} \cdot \mathrm{min}^{-1}\right.$ cooling)), (TEM dark field micrographs using $\gamma^{\prime}$ diffraction spots) : (a) as-solutioned, (b) $650^{\circ} \mathrm{C} / 4 \mathrm{~h}$, (c) $750^{\circ} \mathrm{C} / 4 \mathrm{~h}$, (d) $850^{\circ} \mathrm{C} / 4 \mathrm{~h}$ and (e) $700^{\circ} \mathrm{C} / 24 \mathrm{~h}+800^{\circ} \mathrm{C} / 4 \mathrm{~h}$. 
Effect of the Ageing Treatment. The use of a single-stage ageing treatment instead of the double-stage ageing treatment usually applied for the major disk superalloys presented two advantages : i) a direct relationship between the heat treatment and the effect on microstructure and mechanical properties should be drawn up more easily and ii) it could be technically and economically interesting for the manufacturer. The duration of the ageing treatment was fixed to four hours which could also be an industrial benefit. The effect of the ageing treatment was studied in the range $650-900^{\circ} \mathrm{C}$. Three solutioning temperatures were chosen for this study, 1145,1175 and $1195^{\circ} \mathrm{C}$. This choice will be discussed latter.

Clearly, the ageing treatment had no effect on the dissolution of primary $\gamma^{\prime}$ precipitates and so on the grain size. Three samples were treated at $1175^{\circ} \mathrm{C}$ during 4 hours and aged at 650,750 or $850^{\circ} \mathrm{C}$ for microstructural observations. Two additional microstructures were also observed : as-solutioned and the SHT microstructures. The TEM micrographs of Figure 4 showed that none of the these ageing treatments induced the coarsening of the secondary $\gamma^{\prime}$ precipitates. It could be also noted that tertiary $\gamma^{\prime}$ precipitates were already present in the $\gamma$ channels after the cooling following the solution treatment (Figure 4a). The ageing treatment at $650^{\circ} \mathrm{C}$ led to a higher particle density of the tertiary $\gamma^{\prime}$ population (Figure 4b). These spherical particles generally have a diameter lower than $10 \mathrm{~nm}$ with some bigger ones (15-20 $\mathrm{nm})$ located in the largest $\gamma$ channels or at intersections of channels. After the $750^{\circ} \mathrm{C}$ ageing treatment the tertiary $\gamma^{\prime}$ was on average slightly coarser (Figure $4 \mathrm{c}$ ). Moreover, after the ageing treatment at $850^{\circ} \mathrm{C}$ the tertiary $\gamma^{\prime}$ precipitates were dramatically less numerous than after ageing at lower temperatures (Figure 4d). The finest $\gamma$ channels were free from these particles and the largest ones contained some coarser precipitates $(15$ to $30 \mathrm{~nm})$. The second effect resulting from the ageing at $850^{\circ} \mathrm{C}$ was a spare intergranular precipitation (Figure 5). These particles $\left(\mathrm{M}_{23} \mathrm{C}_{6}\right.$ type carbides) were about $0.1 \mu \mathrm{m}$ thick. The microstructure of the NR3 alloy was also studied after the SHT. The particle density and the size of the tertiary $\gamma^{\prime}$ precipitates were an intermediary state between those observed after an ageing at $750^{\circ} \mathrm{C}$ and $850^{\circ} \mathrm{C}$ (Figure 4e). Very sparse and fine intergranular carbides were also observed.

Microhardness tests were performed on samples solution heat treated at 1145,1175 or $1195^{\circ} \mathrm{C}$ for 4 hours. For the three solutioning temperatures, the maximum of microhardness (peak ageing) was obtained for an ageing temperature close to $750^{\circ} \mathrm{C}$ (Figure 6). It was also observed that the variation of the microhardness with the ageing temperature is higher for the solution treatment at $1175^{\circ} \mathrm{C}$ than for the two other solutioning temperatures. Finally, one can see that a single-stage ageing treatment after a solution treatment at $1175^{\circ} \mathrm{C}$ can lead to a microhardness equal or superior to the value measured on a SHT sample $\left(1175^{\circ} \mathrm{C} / 4 \mathrm{~h}+700^{\circ} \mathrm{C} / 24 \mathrm{~h}+800^{\circ} \mathrm{C} / 4 \mathrm{~h}\right)$.

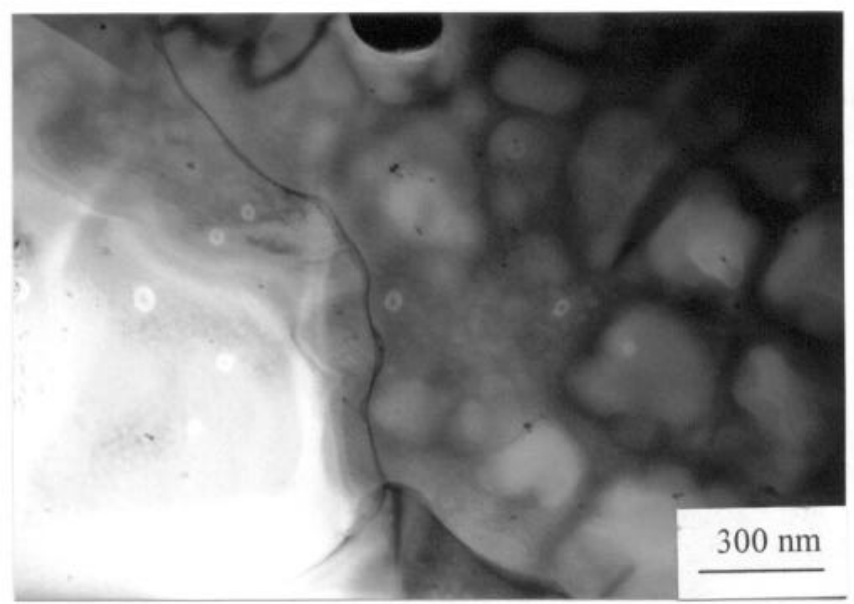

$\uparrow(a)$

(b) $\downarrow$

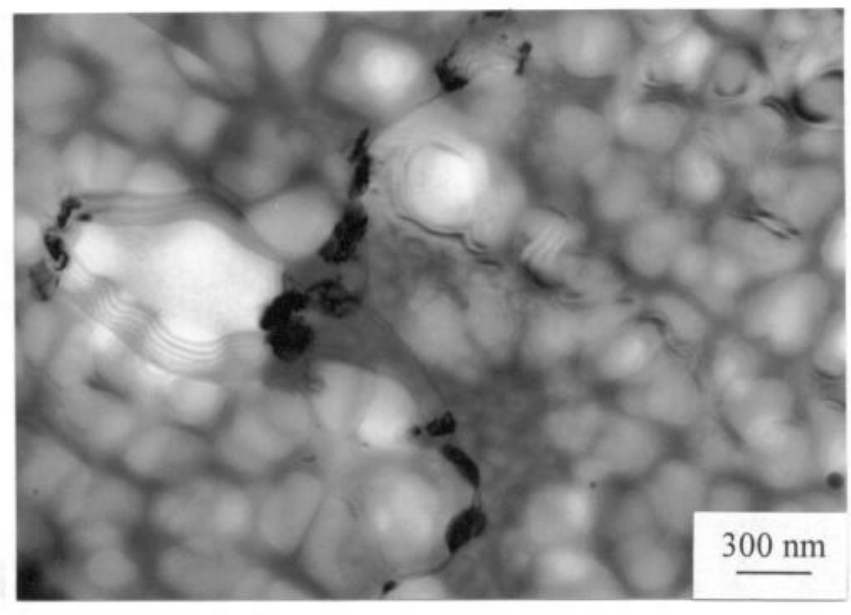

Figure 5: Variation of the grain boundary microstructure with the ageing temperature (solution treatment $1175^{\circ} \mathrm{C} / 4 \mathrm{~h}\left(100 \mathrm{~K} \cdot \mathrm{min}^{-1}\right.$ cooling)) (TEM bright field) : (a) $750^{\circ} \mathrm{C} / 4 \mathrm{~h}$ and (b) $850^{\circ} \mathrm{C} / 4 \mathrm{~h}$.

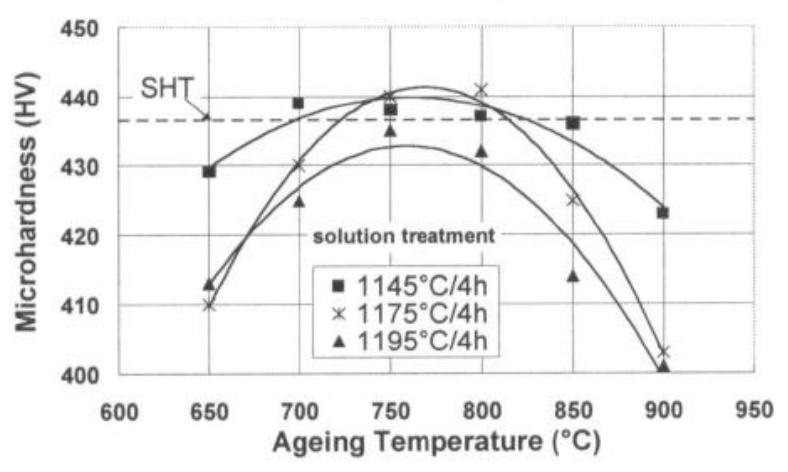

Figure 6: Variation of the microhardness at room temperature with the solutioning temperature and the ageing temperature. 
Selection of the Heat Treatments for Mechanical Assessment. Six heat treatments were selected for tensile and creep tests on the basis of the microstructural observations and of the microhardness results :

- 3 solutioning temperatures with the same ageing temperature

- 4 ageing treatments with the same solutioning temperature.

These different heat treatments are presented in Table III.

Table III Heat Treatments Selected for Mechanical Assessment

\begin{tabular}{ccccc}
\hline & \multicolumn{4}{c}{ Ageing treatment } \\
\cline { 2 - 5 } $\begin{array}{c}\text { Solution } \\
\text { treatment }\end{array}$ & $650^{\circ} \mathrm{C} 4 \mathrm{~h}$ & $750^{\circ} \mathrm{C} / 4 \mathrm{~h}$ & $850^{\circ} \mathrm{C} / 4 \mathrm{~h}$ & $\begin{array}{c}700^{\circ} \mathrm{C} / 24 \mathrm{~h} \\
+800^{\circ} \mathrm{C} / 4 \mathrm{~h}\end{array}$ \\
\hline $1145^{\circ} \mathrm{C} / 4 \mathrm{~h}$ & & $\mathrm{X}$ & & \\
$1175^{\circ} \mathrm{C} / 4 \mathrm{~h}$ & $\mathrm{X}$ & $\mathrm{X}$ & $\mathrm{X}$ & $\mathrm{X}$ \\
$1195^{\circ} \mathrm{C} / 4 \mathrm{~h}$ & & $\mathrm{X}$ & & \\
\hline
\end{tabular}

The common solutioning temperature selected for the study of the influence of the ageing temperature was $1175^{\circ} \mathrm{C}$ because it was the solutioning temperature of the SHT and also the temperature which presented the best potential of hardening with the ageing treatment (see Figure 6). The $1145^{\circ} \mathrm{C}$ solution treatment was sclected because the fine grain size and the fine secondary $\gamma^{\prime}$ precipitate size are open to improve the tensile properties. On the contrary, the $1195^{\circ} \mathrm{C}$ solution treatment was chosen because the coarse grain size and the large fraction of secondary and tertiary $\gamma^{\prime}$ (low fraction of primary $\gamma^{\prime}$ ) should be propitious to creep strength improvement.

The common ageing temperature selected for the study of the effect of the solutioning temperature was $750^{\circ} \mathrm{C}$ because the best microhardness lcvels wcre obtained around this temperature (see Figure 6). The ageing temperatures of $650^{\circ} \mathrm{C}$ and $850^{\circ} \mathrm{C}$ were chosen to estimate the influence of a very fine tertiary $\gamma$ population $\left(650^{\circ} \mathrm{C}\right.$-underageing) and of a sparse and coarse tertiary $\gamma^{\prime}$ population $\left(850^{\circ} \mathrm{C}\right.$-overageing) on the mechanical properties. The double-stage ageing treatment was also applied after the $1175^{\circ} \mathrm{C}$ solution treatment for the mechanical characterisation of the SHT microstructure.

\section{Mechanical Properties}

Tensile Properties. In Tables IV and V are compared the tensile properties of the NR3 alloy at $400^{\circ} \mathrm{C}$ and $700^{\circ} \mathrm{C}$ with the selected microstructures.

At $400^{\circ} \mathrm{C}$, there was a significant effect of the solution treatment on the yield stress (Y.S.) and the ultimate tensile stress (U.T.S.). Finer were the grain size and the secondary $\gamma^{\prime}$ precipitate size and higher were the tensile properties. On the other hand, for a given solutioning temperature, the maximum of tensile properties was reached with the $750^{\circ} \mathrm{C}$ ageing treatment. These two effects were qualitatively predicted by the hardness tests at room temperature.

Table IV Influence of the Heat Treatment on Tensile Properties at $400^{\circ} \mathrm{C}$ of NR3 Alloy (average of 2 tests)

\begin{tabular}{cccc}
\hline Heat treatment & $\begin{array}{c}0.2 \% \text { Y.S. } \\
(\mathrm{MPa})\end{array}$ & $\begin{array}{c}\text { U.T.S. } \\
(\mathrm{MPa})\end{array}$ & $\begin{array}{c}\text { Elongation } \\
(\%)\end{array}$ \\
\hline $1145^{\circ} \mathrm{C} / 4 \mathrm{~h}+750^{\circ} \mathrm{C} / 4 \mathrm{~h}$ & 1043 & 1535 & 24.0 \\
$1175^{\circ} \mathrm{C} / 4 \mathrm{~h}+650^{\circ} \mathrm{C} / 4 \mathrm{~h}$ & 1000 & 1484 & 23.8 \\
$1175^{\circ} \mathrm{C} / 4 \mathrm{~h}+750^{\circ} \mathrm{C} / 4 \mathrm{~h}$ & 1036 & 1515 & 23.3 \\
$1175^{\circ} \mathrm{C} / 4 \mathrm{~h}+850^{\circ} \mathrm{C} / 4 \mathrm{~h}$ & 970 & 1454 & 22.6 \\
$1195^{\circ} \mathrm{C} / 4 \mathrm{~h}+750^{\circ} \mathrm{C} / 4 \mathrm{~h}$ & 987 & 1472 & 23.5 \\
\hline
\end{tabular}

Table V Influence of the Heat Treatment on Tensile Properties at $700^{\circ} \mathrm{C}$ of NR3 Alloy (average of 2 tests)

\begin{tabular}{cccc}
\hline Heat treatment & $\begin{array}{c}0.2 \% \text { Y.S. } \\
(\mathrm{MPa})\end{array}$ & $\begin{array}{c}\text { U.T.S. } \\
(\mathrm{MPa})\end{array}$ & $\begin{array}{c}\text { Elongation } \\
(\%)\end{array}$ \\
\hline $1145^{\circ} \mathrm{C} / 4 \mathrm{~h}+750^{\circ} \mathrm{C} / 4 \mathrm{~h}$ & 1043 & 1255 & 23.2 \\
$1175^{\circ} \mathrm{C} / 4 \mathrm{~h}+650^{\circ} \mathrm{C} / 4 \mathrm{~h}$ & 1002 & 1250 & 18.1 \\
$1175^{\circ} \mathrm{C} / 4 \mathrm{~h}+750^{\circ} \mathrm{C} / 4 \mathrm{~h}$ & 1034 & 1252 & 19.9 \\
$1175^{\circ} \mathrm{C} / 4 \mathrm{~h}+850^{\circ} \mathrm{C} / 4 \mathrm{~h}$ & 981 & 1198 & 22.6 \\
$1195^{\circ} \mathrm{C} / 4 \mathrm{~h}+750^{\circ} \mathrm{C} / 4 \mathrm{~h}$ & 1004 & 1273 & 20.2 \\
SHT & 1022 & 1237 & 21.2 \\
\hline
\end{tabular}

These two influences were also observed for the yield stress at $700^{\circ} \mathrm{C}$ but only the effect of the ageing temperature was verified for the UTS. Coarser grain size and secondary $\gamma^{\prime}$ precipitate size seem to be auspicious for this property at $700^{\circ} \mathrm{C}$. At last, the samples treated with the SHT present tensile properties intermediate between those of the $1175^{\circ} \mathrm{C} / 4 \mathrm{~h}+750^{\circ} \mathrm{C} / 4 \mathrm{~h}$ and the $1175^{\circ} \mathrm{C} / 4 \mathrm{~h}+850^{\circ} \mathrm{C} / 4 \mathrm{~h}$ treatments.

Globally, the most efficient heat treatment to improve the tensile properties was a low solutioning temperature associated with the ageing temperature corresponding to the peak ageing condition. All these results also showed that the presence of tertiary $\gamma^{\prime}$ precipitates in the $\gamma$ channel is an essential condition for high tensile properties.

Creep Rupture Properties. Creep rupture tests were conducted at $700^{\circ} \mathrm{C}$ with an initial load of $700 \mathrm{MPa}$ in order to assess the effects of the different microstructures. All the creep curves are plotted in Figures 7 and 8 and some creep data are presented in Table VI. 
Table VI Influence of the Heat Treatment on the Typical Creep Data of NR3 Alloy $\left(700^{\circ} \mathrm{C} / 700 \mathrm{MPa}\right)$ (average of 2 tests)

\begin{tabular}{cccc}
\hline Heat treatment & $\begin{array}{c}\text { Time to } \\
0.2 \% \text { creep } \\
\text { (hours) }\end{array}$ & $\begin{array}{c}\text { Rupture } \\
\text { time } \\
\text { (hours) }\end{array}$ & $\begin{array}{c}\text { Minimum } \\
\text { creep rate } \\
10^{-9} \mathrm{~s}^{-1}\end{array}$ \\
\hline $1145^{\circ} \mathrm{C} / 4 \mathrm{~h}+750^{\circ} \mathrm{C} / 4 \mathrm{~h}$ & 203 & 460 & 1.4 \\
$1175^{\circ} \mathrm{C} / 4 \mathrm{~h}+650^{\circ} \mathrm{C} / 4 \mathrm{~h}$ & 246 & 491 & 1.6 \\
$1175^{\circ} \mathrm{C} / 4 \mathrm{~h}+750^{\circ} \mathrm{C} / 4 \mathrm{~h}$ & 329 & 854 & 0.8 \\
$1175^{\circ} \mathrm{C} / 4 \mathrm{~h}+850^{\circ} \mathrm{C} / 4 \mathrm{~h}$ & 26 & 171 & 21.7 \\
$1195^{\circ} \mathrm{C} / 4 \mathrm{~h}+750^{\circ} \mathrm{C} / 4 \mathrm{~h}$ & 156 & 510 & 2.7 \\
$\mathrm{SHT}$ & 79 & 317 & 7.8 \\
\hline
\end{tabular}

The influence of the solutioning temperature on the creep properties is shown in Figure 7. It appeared that the best behaviour was obtained with the $1175^{\circ} \mathrm{C}$ solution treatment. The two other solutioning temperatures led to the same range of rupture time but with different creep behaviours. The minimum creep rate associated with the $1195^{\circ} \mathrm{C}$ solutioning temperature is 2 times those obtained with the $1145^{\circ} \mathrm{C}$ solutioning temperature but the increase of the creep rate during the tertiary stage is slower. The higher value of the minimum creep rate should be associated with the coarser secondary $\gamma^{\prime}$ precipitate size (and accordingly with the larger $\gamma$ channels) while the slower increase of the creep rate in the tertiary creep should be attributed to the larger grain size obtained with the high solutioning temperature.

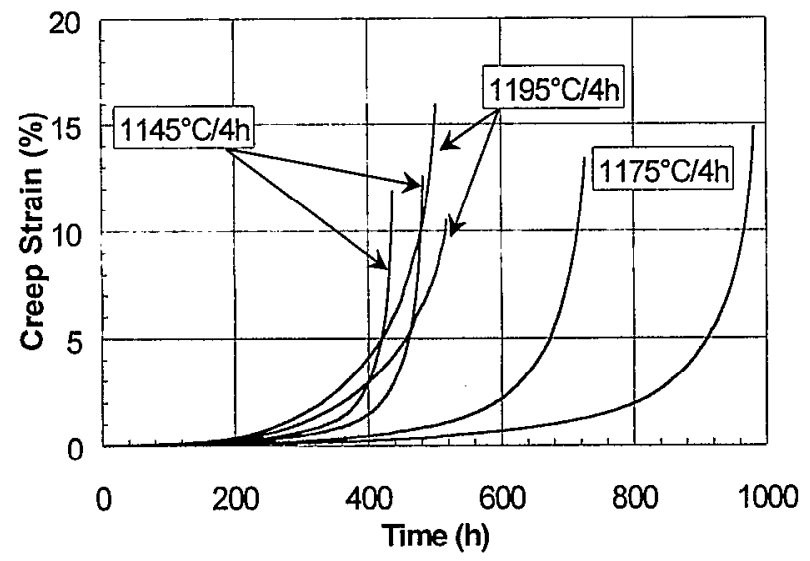

Figure 7: Influence of the solutioning temperature on the creep behaviour of $\mathrm{NR} 3$ alloy $\left(700^{\circ} \mathrm{C} / 700 \mathrm{MPa}\right.$ ) (with an ageing treatment at $750^{\circ} \mathrm{C} / 4 \mathrm{~h}$ ).

The effect of the ageing treatment on the creep behaviour is illustrated in Figure 8. As seen for the tensile properties, the best creep behaviour was obtained with the ageing treatment at $750^{\circ} \mathrm{C}$. In the same way, the overageing treatment $\left(850^{\circ} \mathrm{C} / 4 \mathrm{~h}\right)$ is drastically deleterious for the creep behaviour (rupture time 5 times lower and minimum creep rate about 25 times higher in comparison with the best results). On the other hand, the underageing treatment $\left(650^{\circ} \mathrm{C} / 4 \mathrm{~h}\right)$ led to a creep behaviour significantly worse than for the $750^{\circ} \mathrm{C}$ ageing. However, the $650^{\circ} \mathrm{C}$ ageing treatment induce better creep properties than those obtained with the double-stage ageing treatment (SHT).

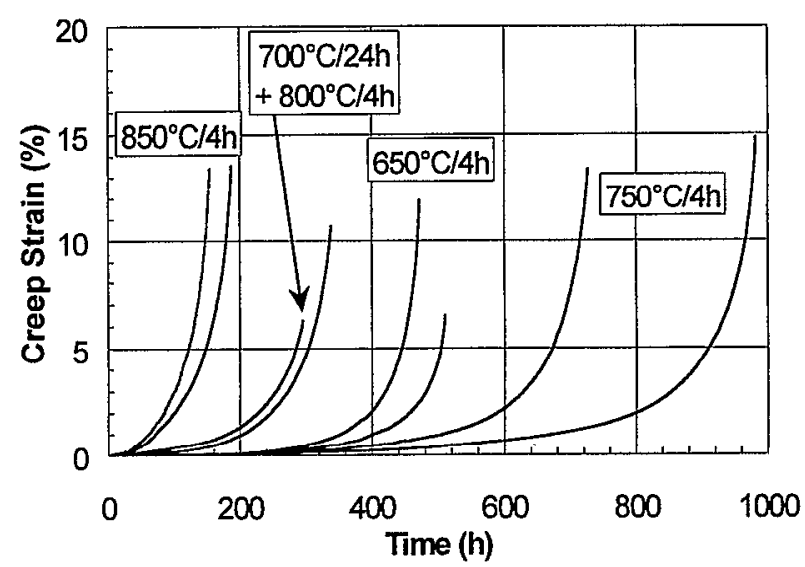

Figure 8: Influence of the ageing temperature on the creep behaviour of NR3 alloy $\left(700^{\circ} \mathrm{C} / 700 \mathrm{MPa}\right.$ ) (with a solution treatment at $1175^{\circ} \mathrm{C} / 4 \mathrm{~h}$ ).

\section{$\underline{\text { Discussion }}$}

\section{Heat Treatment - Microstructure Relationship}

The increase of the subsolvus solutioning temperature led to the following microstructural modifications :

- decrease of the fraction of the primary $\gamma^{\prime}$ precipitates which implies the increase of the secondary and tertiary $\gamma^{\prime}$ fraction and the increase of the average grain size

- increase of the secondary $\gamma^{\prime}$ precipitate size associated to a lower precipitate density.

Some dilatometric experiments were conducted in order to understand this second phenomenon. The starting precipitation temperature (Tsp) was measured during the cooling following the thermal cycle "room temperature-isothermal subsolvus solution treatment (4 hours)-room temperature". The heating and cooling were conducted at a rate of $10 \mathrm{~K} \cdot \mathrm{min}^{-1}$. The dilatometric experiments were performed on two experimental superalloys of the same series (NR3 and NR6 alloys (5)). The results presented in Figure 9 showed that the Tsp decreased with the solutioning temperature. A gap of about - $30 \mathrm{~K}$ was observed between the Tsp and the solutioning temperature in the temperature range studied.

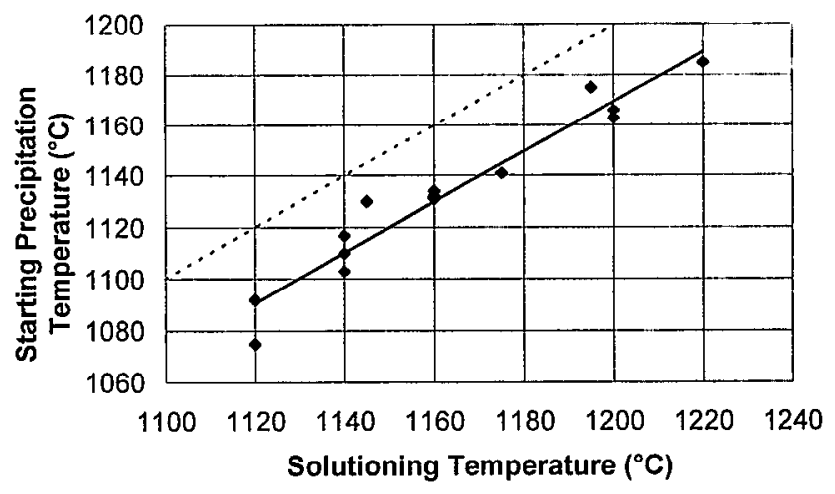

Figure 9: Influence of the solutioning temperature on the starting precipitation temperature of the NR3 and NR6 superalloys. 
The microstructural changes associated to the cooling rate increase (which led to the Tsp decrease) in several superalloys were an increase of the secondary $\gamma^{\prime}$ precipitate density and a decrease of their mean size $(10,11)$. In the present case, the Tsp decrease was not due to a higher cooling rate but to a lower solutioning temperature.

The increase of the ageing temperature led to the increase of the mean size of the tertiary $\gamma^{\prime}$ precipitates and to the decrease of their particle density. The solvus temperature of the tertiary $\gamma^{\prime}$ is close to $850^{\circ} \mathrm{C}$ for an ageing duration of 4 hours. This value is in good agreement with those determined by Wlodek for the N18 alloy and the René 88 DT alloy $(4,12)$. On the other hand, a sparse intergranular precipitation of carbides was observed after the double-stage ageing and the $850^{\circ} \mathrm{C}$ treatments.

\section{Microstructure - Mechanical Property Relationship}

Globally, the highest tensile properties of the NR3 alloy at 400 and $700^{\circ} \mathrm{C}$ were obtained with a microstructure presenting the following features :
a fine grain size
a fine secondary $\gamma^{\prime}$ size
and a slightly coarsened tertiary $\gamma^{\prime}$ precipitates.

The highest UTS at $700^{\circ} \mathrm{C}$ was reached with coarse grain size (12 $\mu \mathrm{m}$ instead of $4 \mu \mathrm{m}$ ) and secondary $\gamma^{\prime}$ precipitate size but the previously described microstructure led however to an UTS value not so lower. The lower tensile properties were always associated to the almost complete dissolution of the tertiary $\gamma^{\prime}$ precipitates. So, it appears that a secondary $\gamma^{\prime}$ precipitate size as fine as possible is required for high tensile properties. On the other hand, as for the hardness, improved tensile properties could be reached by optimising the tertiary $\gamma^{\prime}$ size by appropriate ageing treatment.

Our experimental results are in agreement with those published by Jackson and Reed [9] on the Udimet 720Li alloy. They demonstrated indeed that by using a single-stage ageing treatment, it was possible to obtain an optimum $\gamma^{\prime}$ precipitate size leading to comparable to or even better tensile and hardness properties than those produced through a standard two-stage ageing procedure. Applying standard precipitate hardening theories $(13,14)$ Jackson and Reed showed that this optimal $\gamma^{\prime}$ size corresponds to the transition between $\gamma^{\prime}$ cutting mechanisms involving pairs of weakly coupled $a / 2<110\rangle$ dislocations and pairs of strongly coupled dislocations (9). A similar analysis could be therefore applied to the results obtained on NR3, but further TEM observations would have to be performed in the future to completely validate it.

As the creep behaviour of NR3 is concerned, the effects of the size and distribution of the tertiary $\gamma^{\prime}$ precipitates were even more spectacular than for the tensile properties. In particular, the almost complete dissolution of the tertiary $\gamma^{\prime}$ particles resulting from the ageing treatment for 4 hours at $850^{\circ} \mathrm{C}$ led to poor creep characteristics. TEM observations were carried out on thin foils prepared from specimens aged at 650,750 and $850^{\circ} \mathrm{C}$, then creep strained at $700^{\circ} \mathrm{C}$. The three samples exhibited similar dislocation substructures : stacking faults extended through the $\gamma$ and $\gamma$ ' phases and isolated $a / 2<110\rangle$ dislocations homogeneously distributed between the secondary $\gamma^{\prime}$ precipitates (see Figure 10a).
The extended stacking faults are produced by $\{111\}<112>$-type glide involving shearing of the $\gamma^{\prime}$ precipitates by a/3<112> superlattice partials as observed for instance during creep at $650^{\circ} \mathrm{C}$ of the PM René 95 alloy (15). The sinuous shape of the matrix dislocations is typical of a motion combining slip and climb deformation mechanisms around the secondary $\gamma^{\prime}$ precipitates. Such a deformation process was also identified during creep of René 95 (15) (Figure 10b).

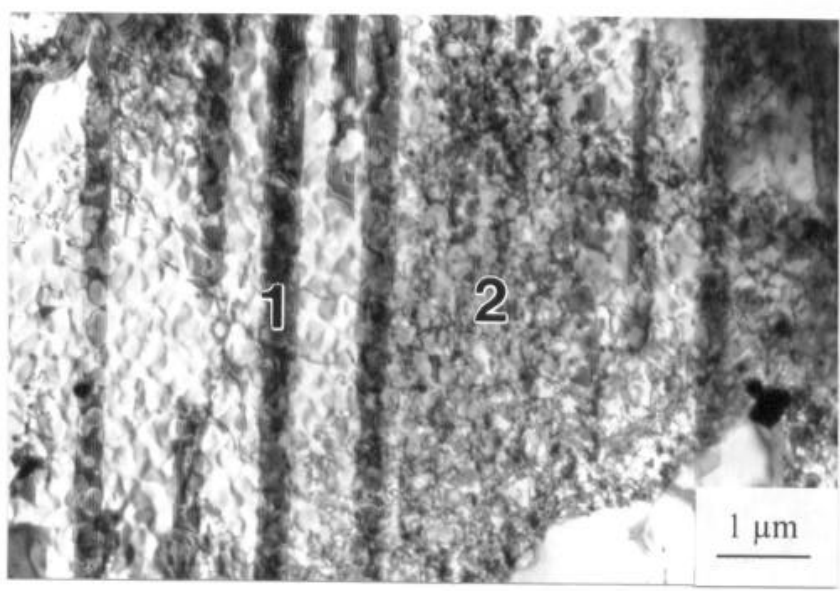

(a)

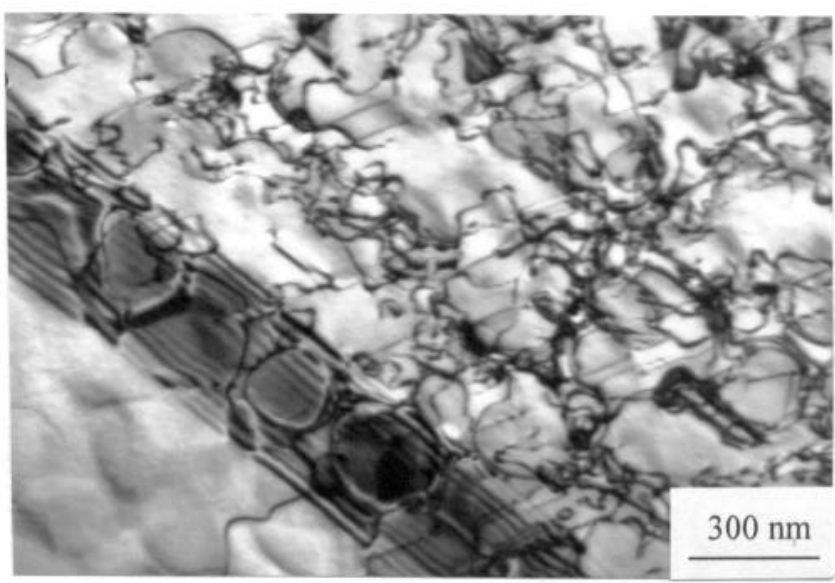

(b)

Figure 10: Dislocation substructures of a specimen aged at $650^{\circ} \mathrm{C} / 4 \mathrm{~h}$ and then creep tested at $\mathrm{T}=700^{\circ} \mathrm{C}$ and $\sigma=700 \mathrm{MPa}$ ( $0.32 \%$ strain) (TEM bright field) : (a) zone 1 ; extended stacking faults and zone 2 : homogeneous distribution of matrix dislocations and (b) sinuous shape of $a / 2<110>$ dislocations between the secondary $\gamma^{\prime}$ precipitates.

Due to their large extents, the stacking faults appeared as prominent features of the deformation structure in the crept NR3 samples. The corresponding $<112>$-type dislocation density is however rather low compared to the $a / 2<110\rangle$ matrix dislocation density and the dominant creep mechanism in the tested specimens is thought to be the motion of $a / 2<110>$ dislocations between the secondary $\gamma^{\prime}$ precipitates. As the motion of these dislocations involves the by-passing of the tertiary $\gamma^{\prime}$ particles, it is obvious that their size and density will have significant effects 
on the creep behaviour, that was effectively experimentally observed. As no paired dislocations were observed in the creep strained samples, it is possible to rule out the cutting mechanism of the $\gamma^{\prime}$ precipitates by strongly coupled $a / 2<110>$ dislocations as observed during tensile deformation of Udimet $720 \mathrm{Li} \mathrm{(9).} \mathrm{On}$ the other hand, $\gamma^{\prime}$ shearing by loosely coupled $\left.a / 2<110\right\rangle$ pairs is likely for the fine tertiary precipitates, but not easy to cvidencc within the rather narrow channels separating the secondary $\gamma^{\prime}$ precipitates. As the stress needed for this cutting mechanism increases with the size of the precipitates (16), that may explain the decrease of the creep rate observed when the temperature of the single-stage ageing treatment increases from $650^{\circ} \mathrm{C}$ to $750^{\circ} \mathrm{C}$. The creep strength decrease observed when applying the ageing treatment at $850^{\circ} \mathrm{C}$ could be interpreted by a transition to an Orowan-type mechanism combining slip and climb processes with expansion and looping of $a / 2<110\rangle$ dislocations around the coarser and less numerous remaining tertiary $\gamma^{\prime}$ precipitates. More accurate dislocation structure analyses will have however to be carried out to identify precisely the tertiary $\gamma^{\prime}$ particle/dislocation interactions and to confirm these hypotheses.

\section{Conclusion}

A significant improvement of the creep strength of the new PM superalloy NR3 was obtained while keeping high tensile properties. This was reached through the application of a simplified heat treatment sequence. A single-stage ageing treatment was indeed applied after the subsolvus solution treatment instead of the usual double-stage ageing treatment. The solution treatment as well as the ageing treatment were conducted in order to optimise the size and the distribution of the secondary and tertiary $\gamma^{\prime}$ particles. These results have shown the important influence of, firstly, the presence of tertiary $\gamma^{\prime}$ precipitates in the $\gamma$ channels and secondly, of their size and particle density which were modulated by the ageing treatment

\section{Acknowledgements}

This work was supported by the French Ministry of Defence. The authors would like to acknowledge Mrs S. Baudu, F. Passilly and C. Ramusat for their assistance in this study.

\section{$\underline{\text { References }}$}

1. M. Marty et al., French Patent 2737 733, "Superalliages à Base de Nickel Stables à Hautes Températures," 1997.

2. J-Y. Guedou, J-C. Lautridou, and Y. Honnorat, "N18, PM Superalloy for Disks: Develupment and Applications," Superalloys 1992, ed. S.D. Antolovich et al. (Warrendale, PA : TMS-AIME, 1992), 267-276.

3. A. Walder et al, "N18, a New High Strength, Damage Tolerant PM Superalloy for Turbine Discs Application," (Paper presented at the $16^{\text {th }}$ congress of the International Council of the Aeronautical Sciences (ICAS), Jerusalem, Israel, 28 August - 2 September 1988).
4. S.T. Wlodek, M. Kelly, and D. Alden "The Structure of N18," Superalloys 1992, ed. S.D. Antolovich et al. (Warrendale, PA : TMS-AIME, 1992), 467-476.

5. D. Locq, A. Walder, M. Marty, and P. Caron "Development of New PM Superalloys for High Temperature Applications," (Paper presented at the EUROMAT 99 Congress, Munich, Germany, 27 30 September 1999).

6. M. Morinaga et al., "New Phacomp and its Applications to Alloy Design," Superalloys 1984, ed. M. Gell et al. (Warrendale, PA : TMS-AIME, 1984), 523-532.

7. R. Watanabe, and T. Kuno, "Alloy Design of Nickel-base Precipitation Hardened Superalloys," Transactions ISIJ, 16 (1976), 437-446.

8. F.C. Hull, "Estimating Alloy Densities," Metal Progress, n 11 (1969), 139-140.

9. M.P. Jackson, and R.C. Reed, "Heat Treatment of Udimet 720Li: The Effect of Microstructure on Properties," Mat. Sci. and Eng., A259 (1999), 85-97.

10 T. Grosdidier, A. Hazotte, and A. Simon, "Precipitation and Dissolution Processes in $\gamma / \gamma^{\prime}$ Single Crystal Nickel-base Superalloys," Mat. Sci. and Eng., A256 (1998), 183-196.

11 H. Loyer Danflou, "Serrated Grain Boundaries and Resulting Properties at $750^{\circ} \mathrm{C}$ of a P/M Nickel Base Superalloy" (Ph.D. thesis, Paris XI-Orsay, 1993)

12 S.T. Wlodek, M. Kelly, and D. Alden "The Structure of RENE' 88 DT," Superalloys 1996, ed. R.D. Kissinger et al. (Warrendale, PA : TMS, 1996), 129-136.

13 L.M. Brown, and R.K. Ham, Strengthening Methods in Crystals , ed. A. Kelly and R.B. Nicholson (London, : Applied Science Ltd., 1971).

14 W. Hüther, and B. Reppich, Z. Metalk., 69 (1978), 628.

15 P.R. Bhowal, E.F. Wright, and E.L. Raymond, "Effects of Cooling Rate and $\gamma^{\prime}$ Morphology on Creep and Stress-Rupture Properties of a Powder Metallurgy Superalloy," Met. Trans. A, $21 \mathrm{~A}(1990)$, 1709-1717.

16 B. Reppich, "Some New Aspects Concerning Particle Hardening Mechanisms in $\gamma$ 'Precipitating Ni-Base Alloys - $\mathrm{I}$. Theoretical Concept," Acta Met., 30 (1982), 87-94. 